Ионов В. Ценностно-смысловое содержание современной украинской музыкальной историографии: диалогический подход. В статье раскрывается значение эстетического отношения в контексте современной музыкальной культуры, определяется зависимость между феноменом эстетического и ценностносмысловыми интенциями культуры. Путем анализа музыковедческих исследований раскрываются личностно-творческие факторы современной украинской музыкальной историографии.

Ключевые слова: эстетическое отношение, поэтика, ценностносмысловой тезаурус, диалог, личностно-творческая позиция.

Ionov V. Valued-semantic contents of modern Ukrainian musical historiography: dialogic approach. Article is devoted to the value of aesthetic attitude in the context of modern musical culture, dependence is determined between the phenomenon aesthetic and valued-personal-creative factors of the modern Ukrainian musical semantic intensions culture. Historiographies open up by the analysis of musicology researches.

Key words: aesthetic attitude, poetics, valued-semantic thesaurus, dialogue, personal-creative.

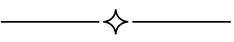

УДК 78.03+78.071.1

\author{
С. Поляковская
}

\title{
ОТ ЗАМЫСЛА К ВОПЛОЩЕНИЮ: КОММЕНТАРИЙ КОМПОЗИТОРА (ПО МАТЕРИАЛАМ ИНТЕРВЬЮ С АЛЕКСАНДРОМ КРАСОТОВЫМ)
}

Содержание статьи находится в кругу проблематики развития современного оперного искусства в Украине. В основу положен материал интервью с одесским композитором А. Красотовым, в котором обсуждаются вопросы стабильности жанрових черт оперы, актуальности традиционных оперных форм, стилистики современного музыкального язы$\kappa a$, специфики оперной драматурги, исполнительской интерпретации и роли музыкальной критики в освещении фактов оперных премьер.

Ключевые слова: опера, оперное творчество А. Красотова, жсанровые черты, стилистика современного музыкального языка.

Пути развития оперного жанра, его жизнеспособность на современном этапе, проблемы и перспективы функционирования оперного театра широко обсуждаются на страницах публикаций музыковедов, культурологов и социологов. От момента зарождения на рубеже

(C) Поляковская С., 2014 
XVI-XVII веков, балансируя между жанрами популярными и элитарными, опера пережила различные этапы от расцвета до упадка и возрождения. И, несмотря на то, что уже более ста лет, по выражению Т. Адорно, «невозможно отделаться от впечатления, что форма оперы устаревает» [1, с. 66], она сохранила не только свои основные жанровые черты, но и ведущее место в ряду репрезентантов академического искусства.

Как синтетический жанр, использующий для эмоционального воздействия на слушателя выразительные возможности всех основных видов искусств, опера практически всю свою историю претендовала на роль концептуального театрального жанра, «музыкального романа», в котором находили отражения как нравственно-этические, так и художественно-эстетические интонации эпохи.

И если в XVIII-XIX веках репертуарная политика оперных театров строилась преимущественно на премьерах, сегодня театральные коллективы выживают за счет постановок классических опер с той или иной степенью интерпретационной свободы. Факты же премьер оперных произведений в современном отечественном театральном мире крайне редки и потому заслуживают особого внимания со стороны историков оперного искусства. Собственно такого рода событию, а именно премьере оперы Александра Красотова «Михаил Воронцов» в Одесском государственном академическом театре оперы и балета, посвящена данная статья. Опера была написана и поставлена в 1994 году и приурочена к 200-летию основания города. Постановка оперы стала ярким и активно обсуждаемым событием в одесском музыкальном мире. В прессе появился ряд рецензий, содержащих как хвалебные, так и критические замечания. На сцене одесского оперного театра прошло три спектакля, после чего страсти постепенно улеглись.

Образовавшаяся временная дистанция, отделяющая нас сегодня от дня премьеры, и созвучность многих тем, поднимаемых в опере, проблемам современного искусства, побудили нас к попытке возврата и переосмысления значения этого произведения в контексте отечественной музыкальной культуры.

Будучи на момент премьеры студентами музыковедческого факультета одесской консерватории, мы пережили это событие живо и эмоционально. Ведь, как уже отмечалось, посещение оперной премьеры для конца XX века - явление не столь уж частое. А фактор личного знакомства с композитором, который на тот момент был ведущим профессором кафедры композиции, еще более оживлял наш 
интерес к происходящему. Переполнявшие нас впечатления от посещения премьеры оперы провоцировали бурные споры, происходившие и в антрактах между действиями, и на лекционных занятиях в консерватории, и во время вечерних чаепитий в общежитии. И в результате появилась статья «Мнения и сомнения», написанная группой студентов IV курса. Несмотря на свою лаконичность, она презентовала кардинально разные, но имеющие право на существование точки зрения в отношении спектакля. Что, к нескрываемой радости авторов, было по достоинству оценено самим Александром Красотовым. Желание продолжения диалога на животрепешущую тему породило идею организовать творческую встречу с композитором, где начинающие музыкальные критики могли бы задать вопросы, чтобы узнать то, что, по выражению Александра Александровича, «при живом авторе можно уточнить».

В беседе, кроме студентов, приняли участие преподаватели кафедры истории музыки и музыкальной этнографии профессор Римма Марковна Розенберг и Сергей Альбертович Таранец. Круг обсуждаемых вопросов, хотя и отталкивался непосредственно от факта премьеры оперы, оказался значительно шире и охватил такие темы, как вопросы этики и морали, осмысление ключевых исторических событий, проблемы стилистики современного музыкального языка, исполнительской интерпретации и объективности музыкальной критики. По счастью, сохранившаяся запись, произведенная во время встречи, предоставляет нам возможность услышать высказывания одного из ярчайших представителей одесской композиторской школы 2-й половины XX - начала XXI века. Позволю себе привести краткую информацию о жизни и творчестве композитора.

Александр Александрович Красотов родился 5 мая 1936 года в Одессе. В 1959 году окончил Одесскую государственную консерваторию (ныне Одесская национальная музыкальная академия имени А. В. Неждановой) по классу композиции Т. С. Малюковой, фортепиано - Б. А. Чарковского, истории музыки - А. Л. Когана. С того же года - преподаватель Одесской консерватории.

С 1966 года - член Союза композиторов Украины. В 1966-1970 годах и с 1976 года - ответственный секретарь Одесского отделения Союза композиторов УССР. С 1982 года - доцент, с 1991 года профессор Одесской государственной консерватории им. А. В. Неждановой. Основатель южно-украинской композиторской школы, воспитал более 60 учеников, среди которых известные современные 
композиторы Кармелла Цепколенко, Юлия Гомельская, Людмила Самодаева. С 1999 года - почетный профессор композиторского факультета Тяньцзинского музыкального университета (Китай) [4].

Заслуженный деятель искусств Украинской ССР (1987), лауреат национальных и международных конкурсов: Всеукраинского конкурса в Киеве $(1967,1971,1983)$, Международных конкурсов (в Берлине - 1973, в Токио - 1992), областной премии имени Е. Багрицкого (1967). Ушел из жизни 5 октября 2007 года. Автор многочисленных сочинений различных жанров (всего около 300): симфоний, опер, инструментальных концертов, ораторий, кантат, мюзиклов, романсов и песен, музыки к драматическим спектаклям, телепрограммам, кинофильмам [4].

В оперном жанре композитором написаны три произведения: «Конец сказки», либретто В. Тимофеева (1959); «Таежная песня», либретто Р. Розенберг (1977) и «Михаил Воронцов», либретто Р. Бродавко (1994) [2; 3].

Последняя из названых опер стала центральным событием 185-го театрального сезона Одесской оперы. В создании спектакля участвовали музыкальный руководитель и дирижер И. Л. Шаврук, режиссер-постановщик заслуженный артист России В. И. Зайденберг, художник-постановщик заслуженный художник Украины Н. М. Бевзенко-Зинкина, режиссер, ведущий спектакль, заслуженный работник культуры Украины Н. М. Григор.

Исполнительский состав был представлен как именитыми, так и начинающими оперными певцами. Главные роли исполняли: народный артист Украины А. Т. Капустин (Воронцов Михаил Семенович); лауреат международных конкурсов Т. Г. Захарчук (Воронцова Елизавета Ксаверьевна); лауреат международных конкурсов Т. В. Спасская (Завадовская Елена Михайловна); Е. Я. Одинокова (Артур-Потоцкая Софья); В. В. Богачев (Левшин Алексей Ираклиевич); Р. В. Зиневич (Садовский); заслуженный артист Украины С. А. Ковалевский (Штиглиц); заслуженный артист Украины А. И. Дуда (Салтыков); В. В. Павлов (Ордынский); дипломант международных конкурсов А. А. Кистенева (Анна).

Итак, возвращаясь к интервью, данному Александром Красотовым после премьеры оперы «Михаил Воронцов», я хочу предложить приоткрыть занавес и заглянуть в творческую лабораторию композитора, опираясь на его собственные суждения о пройденном пути от замысла к его воплощению. 
Первым из обсуждаемых вопросов стало отношение Александра Александровича к личности Михаила Воронцова. Среди претендентов на роль центрального персонажа оперы были такие исторические фигуры, как Ришелье, Дерибас, Пушкин, которые уже фигурировали в музыкальном спектакле «Всего тринадцать месяцев» с музыкой А. Красотова.

Выбор пал на Воронцова. Композитора, по его словам, заинтересовал тот факт, что губернатор своей властью в 1833 году запретил вывоз хлеба из Одессы, потому что одесситам грозил голод в связи с неурожаем. Цитирую: «Меня поразила параллель, что в 1933 году большевики, наоборот, вывозили хлеб с Украины братским борющимся партиям. Ровно через сто лет советские украинцы вывозили хлеб, обрекая свой народ на погибель от голода. А Воронцов сделал важное для государства дело, он взял на себя ответственность за то, что нарушил договор с западными партнерами, он заплатил неустойку сам и спровоцировал других богатых людей города на это, но предотвратил голод в своем городе. Это ли не главное для нас, это ли не нравственный пример нашим современникам. Не говоря о других аналогичных ситуациях из его жизни».

Попытка раскрыть персонаж прежде всего как разностороннюю личность, показать его с разных сторон, не только как государственного деятеля, спровоцировала появление в оперной драматургии еще одной линии - лирической, раскрывающей взаимоотношения графа с Еленой Завадовской.

Именно этот сюжетный компонент вдохновил композитора к написанию музыки. Цитирую: «Для меня была первой фраза, с которой началась опера, это фраза «Жизнь без любви, какая это жизнь? Жить только прошлым я не научилась». Вот с этой фразы начала писаться опера. Когда я взял либретто и стал что-то там такое искать, вдруг зазвучала музыка, именно в этом месте. И потом уже пошло все дальше и дальше».

Либретто, написанное Романом Бродавко, как явствует из интервью, вполне удовлетворило композитора. Цитата: «я специально сказал, чтоб текст был прозаический, я не люблю стихотворные тексты. Потому что стихотворный текст сковывает ритмику. Даже в песне. Я подавляющее большинство своих песен писал так, что сначала создавалась музыка, а потом писался текст. Я по-прежнему убежден, что так получаются песни более яркие мелодически, более своеобразные. Но, во всяком случае, даже стихи в романсах или в песнях я студентов 
своих учу прочитывать не как стихи, не как ритмованные строчки, а как прозу. То есть акцентируя, чтоб они следовали не за ритмом, не находились в плену ритма произведения, а вслушивались в смысл слова. Так что, конечно, работать с этим либретто мне было очень интересно».

Безусловный интерес представляют для нас сегодня и рассуждения Александра Александровича о специфике музыкальной стилистики оперы. Цитирую: «А что касается музыкального языка, это проблема была. Я очень долго думал о том, каким же должен быть язык. И я посчитал вот что. Друзья, я знаю современный язык, знаю, как это делается, но я прекрасно понимаю и отдаю себе отчет в том, что то, что пишется таким языком, написано для узкого спектра, не спектра даже, а одного из цветов спектра слушателей. Мне хотелось, чтоб опера был поставлена нашим театром. Во-первых, сначала шла речь о том, что она будет ставиться нашей оперной студией. И не секрет, что каждый композитор, как бы он там не прикидывался, он все равно в тайне лелеет надежду, что это будет успех, что то, что он пишет, будет кому-то нужно. Даже Стравинский, который кичился тем, что ему все равно, как будет приниматься его музыка. Ничего подобного, не верьте ему. Нет таких композиторов, которым было бы безразлично. Просто композиторы ориентируются на разные слушательские слои... Слушатели очень многослойны. Как угодить всем? Кому-то понравится, кому-то не понравится. И есть такое даже в статьях: со знаком минус - это эклектика, со знаком плюс - это полистилистика. Понимаете, музыка всегда слушается та, которая уже знакома. Когда остановилась музыка, если человек может пропеть ее дальше, значит, ему нравится, если не может - значит, ему такая музыка не нравится. А тем более на нашу уставшую публику, которой вообще не до музыки, вообще не до оперы... И я подумал, почему бы в XIX веке не могли бы спеть романс и стилизацию? Ведь то, что поет Алена Кистенева на стихи Байрона - это действительно стилизация русского романса. Вы обратили внимание, что первая картина, например, там, в оркестре, так сказать, какие-то алеаторические, сонористические вещи. В рамочки взятый аккомпанемент, реплики медных Шаврук показывал просто во время пауз между репликами действующих лиц. Вплоть до вступления Воронцова там идут совершенно такие явные алеаторические вещи, то есть я показал, что я это умею делать. Вначале я это показал. Ну а потом, я не знаю, мне показалось, что это было бы нарочито, неестественно и не слушалось бы». 
Попытки выявить жанровую природу оперы увенчались лишь определением, данным в вышеуказанной статье - «лирико-гражданственные сцены». Так как сам композитор категорически настаивал на том, что для него всякие жанровые дефиниции вторичны и в процессе творчества никакой роли не играли. Что же касается особенностей драматургии оперы, следует отметить, что наряду с традиционными решениями композитор, либреттист и постановщик спектакля пытались придать ему динамичности, некоторой «киношности», «кадровости». Так как, по мнению А. Красотова, «все жанры хороши, кроме скучного». И замечания, что его опера получилась короткая, а в развитии отдельных образов наблюдается некоторая поспешность, он расценил скорее как комплимент: «Нет поспешности, есть динамика, со знаком плюс».

Причем сольные вокальные номера воспринимаются как некоторые «стоп-кадры». Цитирую: «Итак, была написана сначала пьеса, потом мы посидели, подумали, где могут быть стоп-кадры, то есть где можно раскрыть внутренние какие-то переживания героев. Только, не дай бог, недолго. Чтоб, не дай бог, не утомить слушателя. А что вы думаете, об этом не надо думать? Вот и получились такие небольшие стоп-кадрики... Вот эти небольшие ариозо - это, действительно, дань традиции. Все и так говорят, что негде петь, всем нужна кантилена, а мне нужно действие».

Стремление к драматургии сквозного типа привело к появлению упреков со стороны исполнителей в отношении того, что после развернутых сольных номеров, характеризующих тот или иной образ, композитор сразу переключается на следующую картину, не оставляя места для заслуженных оваций. Сохраняя присущее ему прекрасное чувство юмора, Александр Александрович обещает, что «идя навстречу пожеланиям примадонны, вырежет этот такт и поставит «пум» у контрабасов».

Причину отсутствия в опере традиционных ансамблевых сцен автор объясняет так: «Меня вообще жутко с детства раздражало, когда все поют одновременно, меня раздражает, когда я не слышу слов. О чем там они поют, что это такое?.. У меня не было задачи делать ансамбль. Я не хотел. Когда люди говорят одновременно - это значит, они не слышат друг друга. Так ведь? В жизни так? Да, оперный жанр диктует... Я не посчитал здесь это нужным делать. Это уже была бы такая условность, такая ходульность».

Огромное внимание в музыкальном воплощении сюжета композитор уделил лейтмотивной работе, что, к сожалению, не было от- 
мечено критиками. «Ни слова о лейтмотивной работе почему-то не было, - констатирует А. Красотов, - ни слова о своеобразии интонаций каждого персонажа. И особенно второстепенных. Вы заметили, что Левшин и Садовский говорят на одних и тех же мотивах. И оркестр договаривает то, что звучало в самом начале. То есть вытягивается единая интонационная сфера персонажа. Вот это мне хотелось бы, чтобы заметили».

Значительная часть обсуждения была посвящена проблемам исполнительской интерпретации, степени соответствия авторского видения характеров персонажей и их сценического воплощения исполнителями главных ролей. Александр Александрович отметил, что в целом исполнительский состав спектакля справился с поставленными творческими задачами, и сценические образы были максимально близки авторской концепции. Ведь в основном вокальные партии писались под конкретных исполнителей.

Многочисленные «лирические» отступления, то и дело возникавшие в процессе разговора, содержат интересные замечания о творчестве современных композиторов: «Для меня есть авторитеты такие, которые, если я что-то не понимаю в этой музыке, значит, я вижу причину в себе, а не в нем, понимаете? В какой-то степени для меня стал таким авторитетом Шнитке. Для меня был безупречный авторитет - это Борис Чайковский, великолепнейший композитор, просто по своей скромности человеческой он не звучит, для меня был авторитет Моисей Вайнберг, ну и, конечно, Шостакович. Я просто называю тех, которых вы не так хорошо знаете. Щедрин и, пожалуй, Шнитке».

В заключительной части беседы композитор рассуждает о роли и значении музыкальной критики. Цитата: «Действительно, хотелось бы, чтобы заметили, что существует несколько разных линий. Речь в опере идет не только о вывозе хлеба и так далее. Речь идет об актуальности, о вечности человеческих отношений. Вопросы чести, порядочности, доверия, благородства или подлость, ну, любовь, конечно. Вот эти линии, насколько они актуальны? Вот это мне хотелось бы, чтобы заметили не музыковеды. Разве это что не слышно? Разве текст, вы говорите, насколько он соответствует XIX веку или не соответствует... Но мы не ставили, может быть, такой задачи. Может быть, все-таки лучше, чтоб люди почувствовали, что в те времена были те же проблемы, что и сейчас. Или наоборот, что у нас те же проблемы, что и в XIX веке». 
На студенческий вопрос «Что дальше будет с Вашей оперой? Будет ли она в постоянном репертуаре?» А. Красотов ответил: «Хотелось бы, но это уже зависит не от меня... Опера должна жить».

Итак, рамки статьи позволили нам лишь конспективно изложить те направления рассуждений, которые были освещены Александром Красотовым во время творческой встречи. На наш взгляд, текст интервью представляет безусловный интерес для современного музыкального критика да и просто любителя музыки, что ставит вопрос о поисках возможностей его публикации в полной версии.

Еще одной целью данной статьи было привлечение внимания к творчеству одного из наиболее значительных представителей южно-украинской композиторской школы, незаслуженно обделенного вниманием как со стороны исполнителей, так и со стороны музыковедов. Значительное творческое наследие Александра Александровича Красотова, представляющее разные жанры современного музыкального искусства, еще ждет своих исследователей.

\section{СПИСОК ЛИТЕРАТУРЫ}

1. Адорно Т. Избранное: Социология музыки / Т. Адорно. - М.; СПб.: Университетская книга, 1999. - 445 с.

2. Розенберг Р. М. Олександр Красотов. Творчі портрети українських композиторів. - Київ: Музична Україна, 1984.

3. Розенберг Р. М. Театральные аспекты в произведениях одесских композиторов // Трансформація музичної освіти: культура і сучасність. - Одеса, 2003.

4. Красотов Александр Александрович : [Электронный ресурс]. - Режим доступа : https://ru.wikipedia.org/wiki. - Название с экрана.

Поляковська С. Від задуму до втілення: коментар композитора (за матеріалами інтерв'ю з Олександром Красотовим). Зміст статті знаходиться в колі проблематики розвитку сучасного оперного мистецтва в Україні. В основу покладено матеріал інтерв'ю з одеським композитором О. Красотовим, у якому обговорюються питання стабільності жанрових рис опери, актуальності традиційних оперних форм, стилістики сучасної музичної мови, специфіки оперної драматургії, виконавської інтерпретації та ролі музичної критики у висвітленні фактів оперних прем'єр.

Ключові слова: опера, оперна творчість О. Красотова, жанрові риси, стилістика сучасної музичної мови.

Poliakovska S. From concept to implementation: comment of composer (based on materials of interview with Aleksandr Krasotov). The content of the article is in range of problems of development of the contemporary operain Ukraine. This article is 
based on the interview with the composer Alexander Krasotov, held by the teachersand students of the Musicology department of the Odessa Conservatoryafter thepremierehis opera «Mikhail Vorontsov». The article discusses theissues of stability of operagenre features, the actuality of traditionaloperatic formsat the present stage, the specifics ofoperatic dramaturgy, stylistics of themodernmusical language, the problems ofperforming interpretationand the objectivityof music criticism.

Key words: opera, opera works of A. Krasotov, genre features, stylistics of the modern musical language.

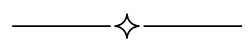

УДК 130.2+78.01(477)

\section{A. Скорик}

\section{ДИСКУРС МАС-МЕДІА В СИСТЕМІ СУЧАСНИХ ДОСЛІДЖЕНЬ КУЛЬТУРОЛОГІЧНОГО ХАРАКТЕРУ}

Стаття присвячена вивченню певного типу дискурсу, у який входять свій стиль, мовний потік, певні чуттєві аспекти, представлені конкретним видом мистецтва. Дискурс характеризується комунікацією у межах окремих каналів, тобто - дискурс візуальний, слуховий, тактильний; визначений правилами спілкування, способом викладу та втілення прагматичної мети оратора - дискурс дидактичний, лайливий, етикетний тощо.

Ключові слова: дискурс, комунікація, практика, межа, культурна комунікація, інформація, інтерпретація, теорія.

Актуальність даного дослідження полягає у з'ясуванні концептів сучасного мислення як єднісної мовної практики, котра маніфестується в формах почуттєвого сприйняття, що необхідні для розуміння тексту і дають уявлення про учасників комунікації. Виокремити факт співвідношення або ж перетинання філософського розуміння феномену «дискурс» 3 його етичним та естетичним навантаженням. Вивченням теми займалися В. Карасік, П. Будьє, С. Неретіна, О. Огурцов, Р. Барт, Г. Маркузе, М. Фуко, Ю. Габермас та ін.

Саме слово «дискурс» походить від грецького - $\Delta \mathrm{t} \varepsilon \xi о \delta о \zeta-$ викладення, розповідь, латинського - discursus/discerre - блукання, розгалуження, бесіда, розмова, французького - discours - промова, виступ, слова. У широкому сенсі дискурс являє собою складну єдність мовної практики і екстралінгвальних факторів (що розуміються як значима поведінка, котра маніфестується в доступному почуттєво-

(C) Скорик А., 2014 